\title{
Genotoxic Effects in Mice Exposed to Radon Emissions in Indoor Conditions. Comparison between in utero and Neonatal Exposures
}

\author{
Cristiano Foschi ${ }^{1}$, Manuel Luís Orta ${ }^{2}$, Licia Radicchi ${ }^{3}$, Germana Szpunar ${ }^{1}$ and Mauro Cristaldi ${ }^{1}$ \\ 1. Department of Biology and Biotechnology Charles Darwin, Faculty of Mathematical, Physical and Natural Sciences, University of \\ Rome, Rome 00161, Italy \\ 2. Department of Cell Biology, Faculty of Biology, University of Seville, Seville 41012, Spain \\ 3. Civic Museum of Zoology, via U. Aldrovandi 18, Rome 00197, Italy
}

\begin{abstract}
The purpose of this study was to develop a biological model to evaluate the genotoxic effects of natural emissions of Radon-222 and its decay products. To this aim, mice of the Swiss CD1 strain were exposed to Radon for different periods (adult life, early postnatal and in utero exposure) and two simple but accurate mutagenicity tests (Micronucleus test and the Comet assay) were applied to the peripheral blood of mice. The study was carried out in two small towns in Latium region-Italy, where radon pollution is notoriously present due to the volcanic soils. One experiment was carried out in the cellar of a house in Ciampino (Rome) and two experiments were performed in an old cellar in Vetralla (Viterbo). The results showed that in all mice groups exposed to natural emissions of radon and its decay products, the micronucleated erythrocytes frequency (ME) was significantly higher than that observed in the mice control. The single cell gel electrophoresis (Comet assay) was performed in lymphocytes of adult mice in the last experiment. The results for this test also show that DNA damage was higher than in the cells of the mice control and the cells of mice exposed for a shorter period of time. To confirm these findings, the single cell gel electrophoresis (Comet assay) was performed in lymphocytes of adult mice in the last experiment. Similarly, this result could be linked to a greater sensitivity of neonatal mice to radon emissions compared with intrauterine mice. Further investigations on the effects of radon and its decay products during the intrauterine life and the first neonatal period should be performed to better clarify its genotoxic activity.
\end{abstract}

Key words: Radon, genotoxicity, DNA damage, micronucleus test, comet assay.

\section{Introduction}

Radon is a radioactive noble gas, chemically inert, decay product of Uranium-238. It is classified by WHO/IARC as group 1 carcinogen. Home (indoor) exposure to short lived radioactive disintegration products of Radon-222 is responsible for about half of all non-medical exposure to ionizing radiation [1]. Uranium-238 is present throughout the earth's crust, but environmental exposure to Radon-222, and its decay products, is especially stronger in dwellings located in areas where the subsoil is rich in Uranium

Corresponding author: Cristiano Foschi, Ph..D., research fields: radon, genotoxicity, natural radioactivity, DNA damage and mutagenicity testing. or Thorium. Radon rises up from the soil surface (some building materials emit large quantities) and tends to accumulate in confined spaces. In addition it can enter buildings through the called "chimney effect" due to pressure imbalance that is created for the highest temperature of the air in confined spaces. This problem affects mainly basements and floor plans, and therefore people who work in tunnels, underpasses and caves (catacombs guides, bank employees, etc.) are continuously exposed to these radioactive isotopes.

Radon has a half life of 3.8 days, allowing it to diffuse from the soil into the air before decaying by emission of $\alpha$ particle into a series of its short lived radioactive progeny. Two of these, Po-218 and Po-214, also decay by emitting $\alpha$ particles. 
Most of the inhaled Radon is immediately exhaled, however it tends to be deposited on the bronchial epithelium, thus exposing cells to irradiation [2]. Since the beginning of the last century a relation between exposure to high radon concentration and lung cancer was observed [3, 4]. Studies of exposed miners have consistently confirmed associations between radon and lung cancer [5, 6]. However, results obtained on the biological effects are hard to explain, because of the differences in several parameters, such as duration and periodicity of exposures, concentration values of radon and products decay, synergic effects of tobacco smoke, etc. Genotoxic properties of Radon have been investigated because they are important in order to understand the events that may involve radon to the onset of neoplasia in cytogenetic studies [7-11].

In this study we present data that demonstrate that Radon exposures in two Italian areas cause genotoxicity in vivo as measured with two standard techniques. Furthermore, our data also suggest that animals in the neonatal period are more sensitive to Radon as compared to fetuses [12, 13].

\section{Materials and Methods}

2.1 Study Sites: Experiments were Carried out in Ciampino (Rome) and Vetralla (Viterbo) (Fig. 1)

2.1.1 Ciampino Experimental Design (13-09-2007/05-10-2007)

Two females CD-1 Swiss in advanced pregnancy (around the 15th gestation day), caged with water and food ad libitum were placed in the cellar of a building. Within three days of the start of the experiment, both females gave birth to 13 newborns. In total 26 newborn mice were exposed to radon gas for 21 days (three days of intrauterine exposure and 18 days of exposure after birth).

2.1.2 Vetralla Experimental design

1st experiment (25-12-2007/29-01-2008):

Three pairs of adult CD-1 Swiss, were placed in three cages. A fourth cage contained the four adult males.
All cages contained water and food ad libitum. The cages were placed in a cellar, six meters below road level. The three pairs gave birth to two, 15 and 11 mice, respectively. In total 28 newborn mice were exposed to radon for 23 days (18 to 19 days of intrauterine exposure and four to five days of exposure after birth).

2nd experiment (18-12-2009/20-01-2010):

Eight adult females CD-1 Swiss, were placed in two cages (four mice per cage), with water and food ad libitum. The cages were placed in a cellar, six meters below the road level, and exposed to radon for about 33 days. The experiments were performed six meters below ground level in Vetralla, and about two meters below ground level in Ciampino.

\subsection{Determination of Radon-222 Activity}

Ciampino cellar: Radon-222 activity measurements were carried out for over 22 days in the proximity of the cages, by an active detector (Radon Scout made by SARAD GmbH, Dresden, Germany).

Vetralla cellar: Radon-222 activity was measured for by an active detector (AWARE Corporation RADIM 5 made by Plch Smm, Czech Republic) and CR 39 passive detectors provided and analyzed by U-Series, Bologna, Italy.

In both instruments (active detectors) the concentration of radon is determined by measuring the $\alpha$-activity of the decay products of the conversion of radon, Polonium-218 and Polonium-214, collected from the detection chamber on the surface of a semiconductor detector by an electric field. The only difference in these two detectors is the time interval used between measurements.

Radon concentrations were calculated by the laboratory "U-Series” (Bologna, Italy).

\subsection{Genotoxicity Testing}

Micronucleus test and the Comet assay were applied to the peripheral blood of mice. Where possible (for adults) the exposed group was tested before being placed in cages to determine average levels of DNA 


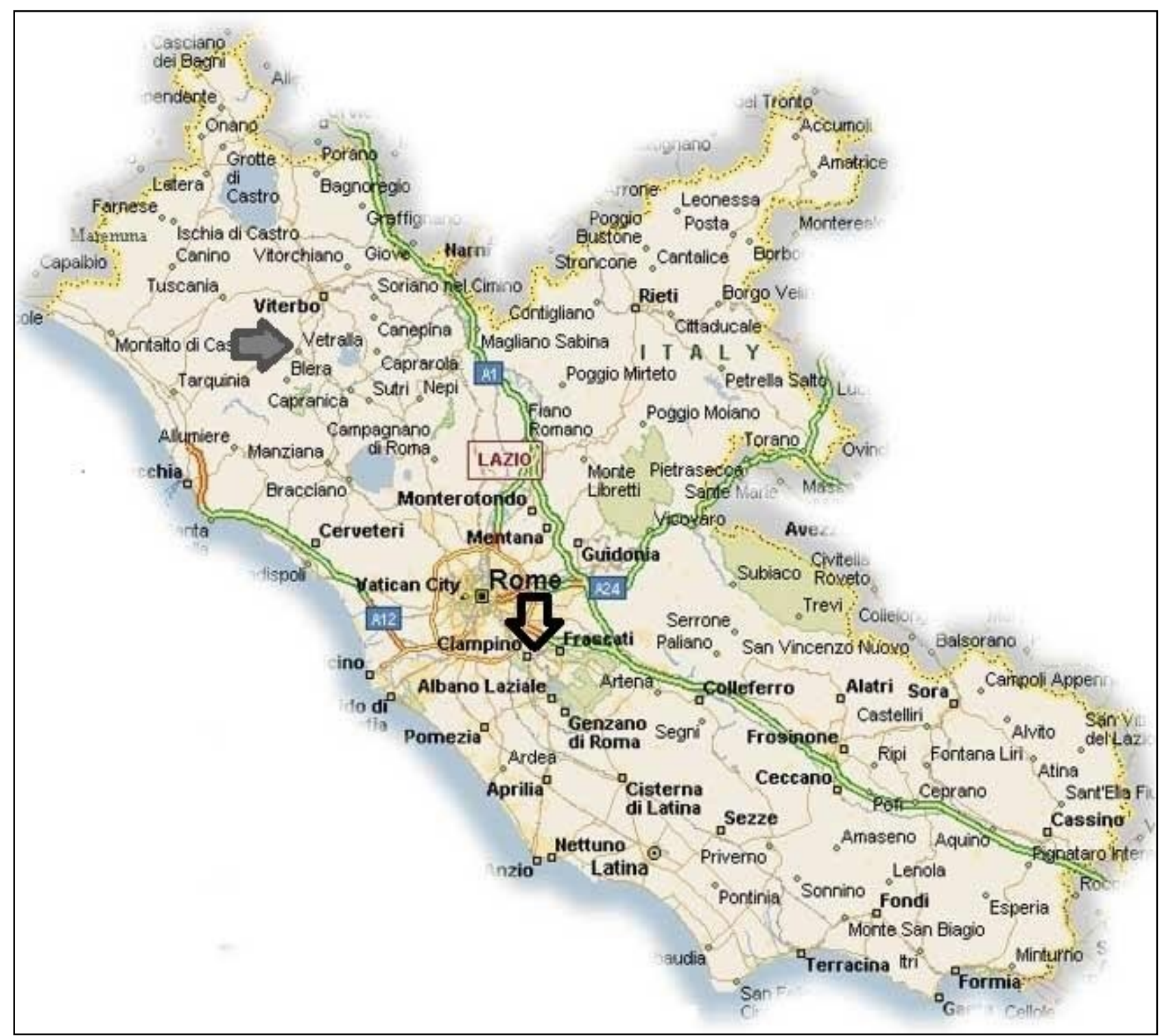

Fig. 1 Map of Latium region; Ciampino is indicated by outlined arrow, Vetralla by solid arrow (source: www.tuttocitta.it).

damage prior to exposure. These mice were immediately tested again after the exposure period. Control mice (newborns and foetuses) of the same strain and age were held in stabulary and tested in the same manner at the end of the exposure time only.

Micronucleus test: smears were prepared by blood samples collected by caudal vein puncture of each animal, avoiding any useless suffering and pain. Slides were coded, fixed in absolute methanol and stained with the May-Grunwald-Giemsa stain. Micronuclei (MN) were scored blindly by the same analyst at 1,000x magnification and micronuclei frequencies were determined counting 2,000 erythrocytes per animal.

In total, 72 mice were exposed and analyzed by micronucleus test (excluding control mice). For adults, blood samples collected from each mouse before the exposure were used as controls. For newborns and foetuses, $\mathrm{N}=9$ mice of the same strain were held in controlled stabulary conditions and used as control mice for the Ciampino experiment. $\mathrm{N}=18$ were used as control mice for Vetralla. 
Comet assay: blood samples were collected by caudal vein puncture, as before described, and placed in Eppendorf tubes $(1 \mathrm{~mL})$. Heparin was used as an anticoagulant and DMSO (10\%) was added before freezing.

Slide preparation: regular slides were coated with a $1 \%$ solution of standard agarose in distilled water, by immersing vertically for $2 \mathrm{~s}$ and air-drying to solidify the agarose. Once the slides were dry and totally transparent, they were kept at $4{ }^{\circ} \mathrm{C}$ and used up to 1 month after preparation. We employed a modification [14] of the protocols described by Singh et al. [15] and Fairbairn et al. [16]. Only $40-100 \mu \mathrm{L}$ of cell solution was embedded in a $0.7 \%$ low melting agarose solution in PBS and immediately pipetted onto the coated slides and then a coverslip was placed on. The slides were incubated at $4{ }^{\circ} \mathrm{C}$ for $10 \mathrm{~min}$. Coverslips were removed and a third (low melting) agarose layer was added, together with new coverslips. Slides were again incubated at $4{ }^{\circ} \mathrm{C}$ for $10 \mathrm{~min}$. Coverslips were finally removed and cells were immersed in lysis solution $(10 \mathrm{mM}$ Tris- $\mathrm{HCl}, 2.5 \mathrm{M} \mathrm{NaCl}, 100 \mathrm{mM}$ $\mathrm{Na}_{2}$-EDTA, $0.25 \mathrm{M} \mathrm{NaOH}, 1 \%(\mathrm{v} / \mathrm{v})$ Triton X-100 and $10 \%(\mathrm{v} / \mathrm{v}) \mathrm{DMSO}, \mathrm{pH} 12.0)$ for $1 \mathrm{~h}$ at $4{ }^{\circ} \mathrm{C}$ in the dark.

Electrophoresis: in order to unwind the DNA, the slides were incubated for $20 \mathrm{~min}$ in electrophoretic buffer containing $1 \mathrm{mM} \mathrm{Na}$-EDTA and $300 \mathrm{mM}$ $\mathrm{NaOH}, \mathrm{pH} 12.8$ (Alkaline conditions). Electrophoresis was carried out at $1 \mathrm{~V} / \mathrm{cm}$ for $20 \mathrm{~min}$. Slides were then neutralized with $3 \times 5 \mathrm{~min}$ washes of $0.4 \mathrm{M}$ Tris- $\mathrm{HCl}$ pH 7.5 to remove alkali and detergent. After that, cells were stained with the fluorochrome 4' 6-diamidino-2-phenylindole (DAPI) in Vectashield (mounting medium for fluorescence $\mathrm{H}-1000$, Vector Laboratories). Slide scoring: DNA damage was analysed using the Comet Score program (an online free Comet scoring software web). Two parameters were estimated for each Comet: (1) DNA damage (percentage migrated DNA in the tail), and (2) tail moment (tail length $\times$ tail intensity or percent migrated DNA). Five different classes of DNA damage were established following classification given by Anderson et al. [16]. Class 1 corresponded to cells showing DNA damage between 0 and $5 \%$, class 2 (5-20\%); class 3 were cells with DNA damage between (2-40\%); class 4 (40-95\%); and class 5 (95-100\%), which corresponds to cells with the highest damage or totally damaged cells. For each experimental point at least 324 Comets were measured.

\subsection{Statistical Analysis}

Micronucleus test: since some of the variables were not normally distributed (Lilliefors test, $P<0.05$ ), we used nonparametric tests. Medians were analysed by Mann-Whitney U-test.

Comet assay: Mann-Whitney test and $\chi^{2}$ (chi-square test) have been used for statistical evaluation.

All statistical analyses were carried out using STATISTICA 6.0 package (StatSoft, Tulsa, OK, USA).

\section{Results and Discussion}

\subsection{Exposures}

Ciampino site: Figure 2 shows the ${ }^{222} \mathrm{Rn}$ concentrations measured using electronic detector Radon Scout in continuum. The mean concentration of the entire period of the exposition of the newborns was $562 \mathrm{~Bq} / \mathrm{m}^{3}$. The graphic shows large yet short variations of radon activity, ranging from the maximum value of $5,054 \mathrm{~Bq} / \mathrm{m}^{3}$ and the minimum value $\left(0 \mathrm{~Bq} / \mathrm{m}^{3}\right)$. Total exposure at the end of period was $260 \mathrm{kBq} \mathrm{h} / \mathrm{m}^{3}$.

Vetralla site: 1 st experiment: Figure 3 shows ${ }^{222} \mathrm{Rn}$ concentrations measured using electronic detector RADIM 5 in continuum. The graphic shows (large short) variations of radon activity, ranging from the maximum value of $12,972 \mathrm{~Bq} / \mathrm{m}^{3}$ and the minimum value of $31 \mathrm{~Bq} / \mathrm{m}^{3}$. The mean value of the total period of the exposure of the newborns was $2,074 \mathrm{~Bq} / \mathrm{m}^{3}$. Total exposure since the start to the end of gestational 


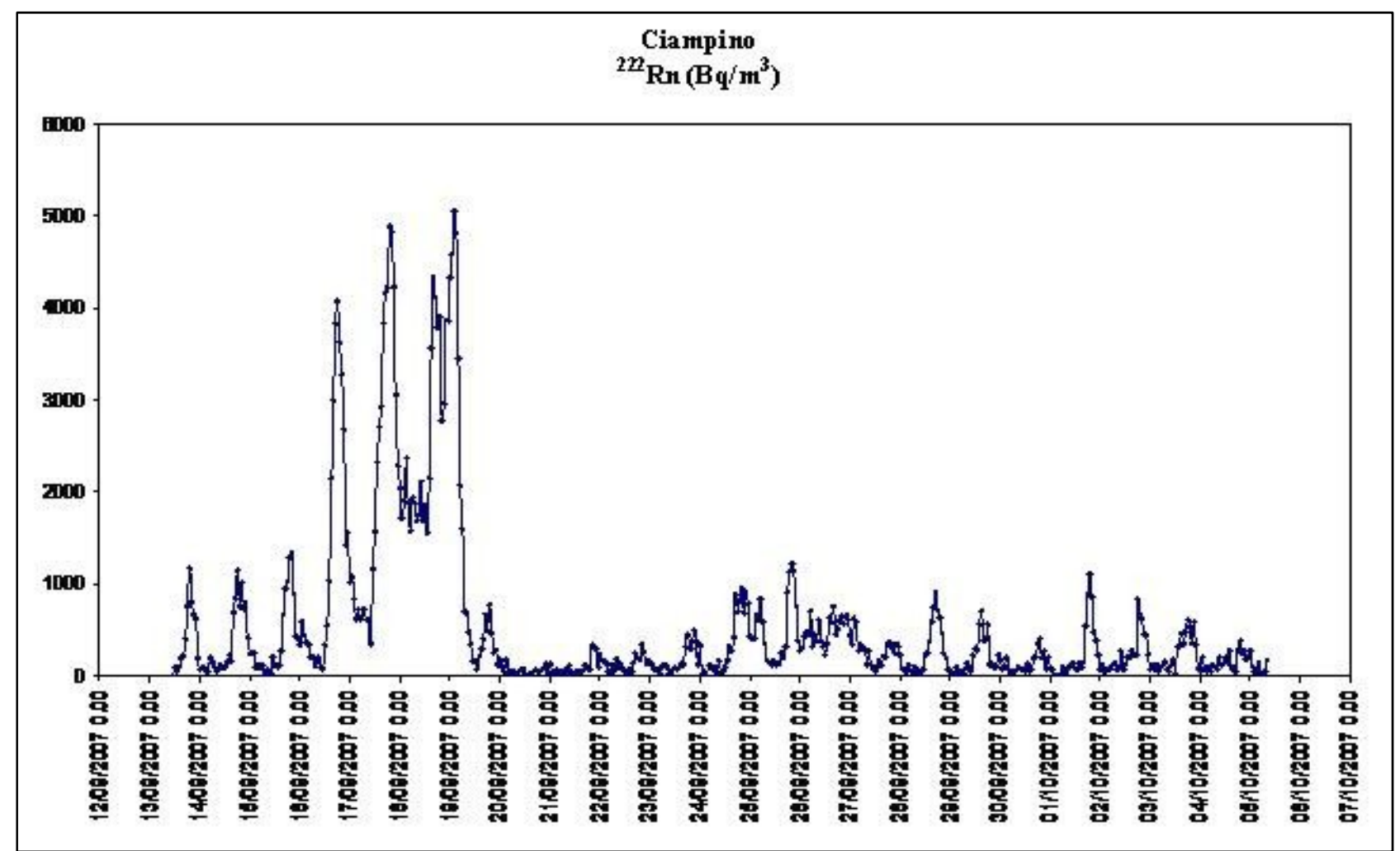

Fig. 2 Graph showing the trend of the concentration of ${ }^{222} \mathrm{Rn}\left(\mathrm{Bq} / \mathrm{m}^{3}\right)$ monitored by the active detector Radon Scout in Ciampino from 12/09/2007 to 07/10/2007.

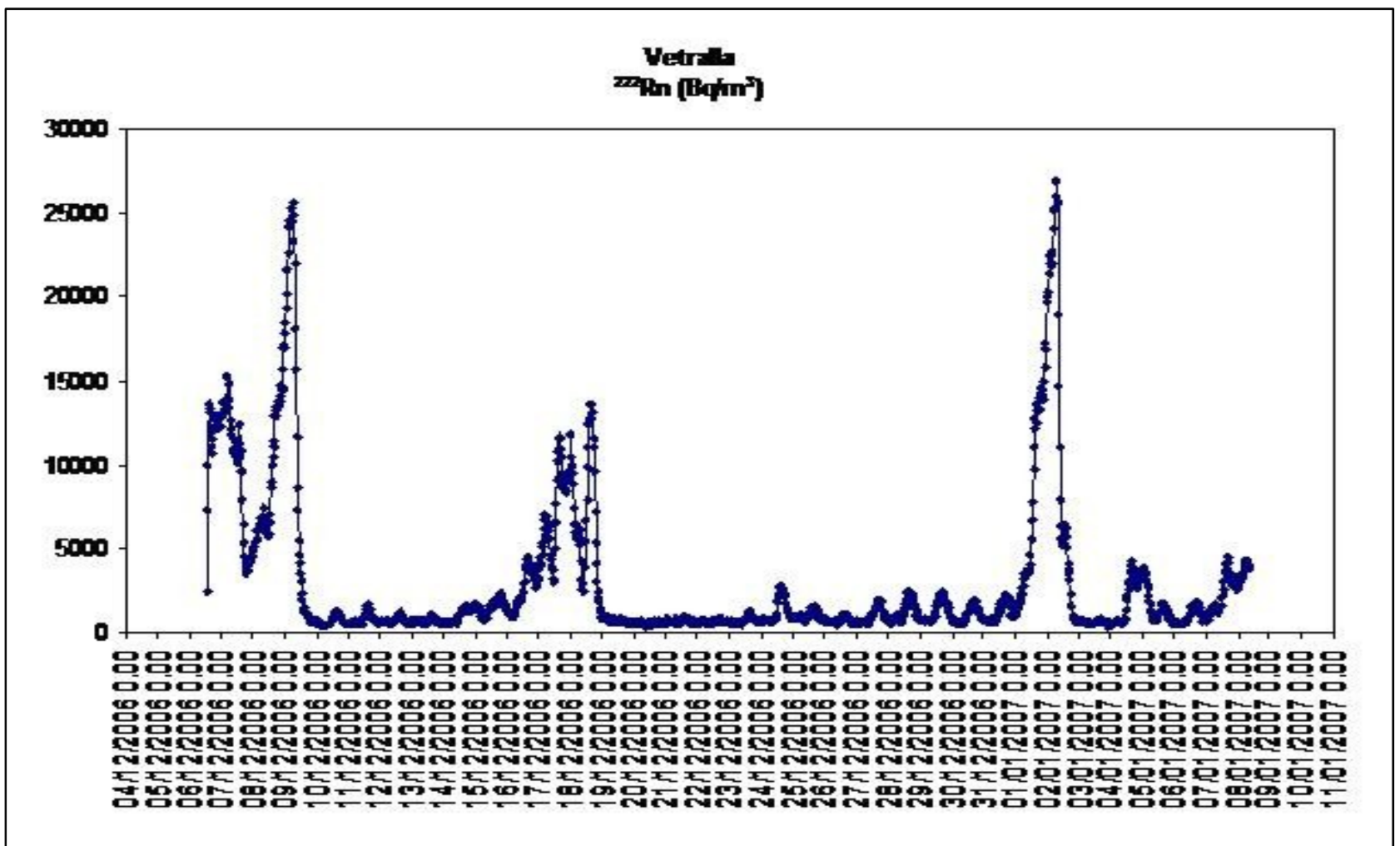

Fig. 3 Graph showing the trend of the concentration of ${ }^{222} \mathrm{Rn}\left(\mathrm{Bq} / \mathrm{m}^{3}\right)$ monitored by the active detector RADIM 5 in Vetralla from $25 / 12 / 2007$ to $30 / 01 / 2008$. 
period was $1,090 \mathrm{kBq} \mathrm{h} / \mathrm{m}^{3}$. Total exposure for adult mice (entire period of 35 days) was $1,700 \mathrm{kBq} \mathrm{h} / \mathrm{m}^{3}$.

2nd experiment: ${ }^{222} \mathrm{Rn}$ concentrations were measured using just passive detectors (CR-39). The exposure was calculated every 10 days (Table 1). The mean concentrations are included between $745 \mathrm{~Bq} / \mathrm{m}^{3}$ to $2,100 \mathrm{~Bq} / \mathrm{m}^{3}$. Total exposure after the last ten days was $200 \mathrm{kBq} \mathrm{h} / \mathrm{m}^{3}$, after twenty days $560 \mathrm{kBq} \mathrm{h} / \mathrm{m}^{3}$ and, since the start to the end of the period, was 1,160 $\mathrm{kBq} \mathrm{h} / \mathrm{m}^{3}$.

With regards to the experiments of newborns and foetuses (Vetralla) the entire exposure period (about 25 days) consisted of about 19 days of intrauterine exposure and five to six days of exposure after birth. These data were compared with those obtained in newborn mice from the cellar in Ciampino exposed to ${ }^{222} \mathrm{Rn}$ for three to four days in utero and 18 days of postnatal exposure (about 22 days in total). The mice located in the Vetralla cellar were exposed to a ${ }^{222} \mathrm{Rn}$ concentration $\left(1,090 \mathrm{kBq} \mathrm{h} / \mathrm{m}^{3}\right)$ almost four times higher compared with the mice exposed in Ciampino's cellar $\left(260 \mathrm{kBq} \mathrm{h} / \mathrm{m}^{3}\right)$.

\subsection{Micronucleus Test}

Micronucleus test was carried out on newborn mice ( $\mathrm{N}=26$ from Ciampino and $\mathrm{N}=28$ from Vetralla) and adult mice $(\mathrm{N}=18)$ from two experiments carried out in Vetralla.

Ciampino site: Table 1 shows the results obtained applying peripheral blood micronucleus test in the newborn mice exposed in Ciampino cellar and in the control mice. It was observed that the frequency of micronucleated erythrocytes is significantly higher in the exposed group compared with the control group ( $P$ $<0.0001)$.

Vetralla site: Table 2 shows the mean frequencies of peripheral blood micronucleus test in all mice offspring born in Vetralla cellar and in the control offspring. It was observed that the frequency of micronucleated erythrocytes is significantly higher in the exposed group compared with the control group $(P$ $<0.05)$.

Vetralla 1st experiment: Table 3 shows the mean frequencies of peripheral blood micronucleus test before exposure and after 35 days in the Vetralla cellar. It was observed that the frequency of micronucleated erythrocytes is significantly higher in the exposed group compared with the control group $(P<0.05)$.

Vetralla 2nd experiment: Table 4 shows the mean frequencies of peripheral blood micronucleus test before exposure and after 33 days in the Vetralla cellar. It was observed that the frequency of micronucleated erythrocytes is significantly higher in the exposed group compared with the control group ( $P$ $<0.001)$.

In the experiment carried out in Ciampino, the genotoxic damage observed in newborn mice exposed to a low indoor radon concentration $\left(300 \mathrm{kBq} \mathrm{h} / \mathrm{m}^{3}\right)$ may be related to the period in which the animals were exposed. It should be noted that in this case the females were exposed on the 15th the day of pregnancy. Therefore the newborn mice were exposed for fewer days during the intrauterine life (4-5) and for 18 days after birth, compared with the mice in the Vetralla cellar which were exposed for the whole intrauterine phase and only for few days (4-5) after birth.

Table $1{ }^{222} \mathrm{Rn}$ concentrations measured by passive detectors (CR-39) and relative exposures.

\begin{tabular}{llll}
\hline & \multicolumn{3}{c}{ Vetralla $2^{\text {nd }}$ experiment } \\
\hline Time of exposure & $\begin{array}{l}\text { Concentrations } \\
222\end{array}$ & $\begin{array}{l}\text { Exposure }\left[\mathrm{Bq} / \mathrm{m}^{3}\right] \\
{\left[\mathrm{kBq} \mathrm{h} / \mathrm{m}^{3}\right]}\end{array}$ & Total exposure $\left[\mathrm{kBq} \mathrm{h} / \mathrm{m}^{3}\right]$ \\
\hline $18 / 12 / 2008-29 / 12 / 2008$ & $745 \pm 170$ & $200 \pm 40$ & $200 \pm 40$ \\
$29 / 12 / 2008-09 / 01 / 2009$ & $1,500 \pm 350$ & $360 \pm 80$ & $560 \pm 90$ \\
$09 / 01 / 2009-19 / 01 / 2009$ & $2,100 \pm 450$ & $600 \pm 130$ & $1,160 \pm 250$ \\
\hline
\end{tabular}


Table 2 Mean frequencies \pm SD of micronucleated erythrocytes in newborn mice exposed in Ciampino cellar. $\mathbf{N}=$ number of animals; ME = Micronucleated Erythrocytes; $E$ = Erythocytes; Control = mice not exposed (from stabulary at the Sapienza University, Rome); significance respect to control: $b=P<0.01 ; d=P<0.0001$.

\begin{tabular}{llll}
\hline & \multicolumn{1}{c}{ Ciampino } \\
\hline Control & $\mathrm{N}$ & $\mathrm{ME} / 1,000 \mathrm{E}$ & Exposure $\left[\mathrm{kBq} \mathrm{h} / \mathrm{m}^{3}\right]$ \\
Exposed & 9 & $0.83 \pm 0.66$ & - \\
\hline \multicolumn{5}{c}{} & $3.65^{\mathrm{d}} \pm 2.27$ & 260 \\
\hline & 26 & Vetralla & Exposure $\left[\mathrm{kBq} \mathrm{h} / \mathrm{m}^{3}\right]$ \\
\hline Control & $\mathrm{N}$ & $\mathrm{ME} / 1,000 \mathrm{E}$ & - \\
Exposed & 18 & $1.25 \pm 0.7$ & 1,090 \\
\hline
\end{tabular}

Table 3 Mean frequencies \pm SD of micronucleated erythrocytes in adult mice exposed in Vetralla cellar. $N=$ number of mices; $\mathrm{ME}=$ Micronucleated Erythrocytes; $\mathrm{E}=$ Erythocytes; Control $=$ blood samples before exposure; significance respect to control: $\mathbf{a}=\boldsymbol{P}<\boldsymbol{0 . 0 5}$.

\begin{tabular}{lllll}
\hline \multicolumn{5}{c}{ Vetralla 1st experiment } \\
\hline Control (before exposure) & $\mathrm{N}$ & Male/female & $\mathrm{ME} / 1,000 \mathrm{E}$ & Exposure $\left[\mathrm{kBq} \mathrm{h} / \mathrm{m}^{3}\right]$ \\
\hline Exposed & 10 & $7 / 3$ & $0.75 \pm 0.49$ & - \\
\hline
\end{tabular}

Table 4 Mean frequencies \pm SD of micronucleated erythrocytes in adult mice exposed in Vetralla cellar. $N=$ number of mice (females); ME = Micronucleated Erythrocytes; $\mathrm{E}=$ Erythocytes; Control = blood samples before exposure; significance respect to control: $\mathbf{c}=\boldsymbol{P}<\mathbf{0 . 0 0 1}$.

\begin{tabular}{llll}
\hline & \multicolumn{3}{c}{ Vetralla 2nd experiment } \\
\hline & $\mathrm{N}$ & $\mathrm{ME} / 1,000 \mathrm{E}$ & Exposure $\left[\mathrm{kBq} \mathrm{h} / \mathrm{m}^{3}\right]$ \\
\hline Control (before exposure) & 8 & $0.94 \pm 0.56$ & - \\
Exposed & 8 & $2.25^{\mathrm{c}} \pm 0.46$ & 1,160 \\
\hline
\end{tabular}

\subsection{Comet Assay}

In the present study we have made use of the rapid method applicable to mammalian lymphocytes, which do not need to be isolated with the potentially cytotoxic drug Ficoll, as previously described by Daza et al. [13]. As we can see in Table 5, DNA damage assessed by the Comet assay in mice after final exposure $\left(1,160 \mathrm{kBq} \quad \mathrm{h} / \mathrm{m}^{3}\right)$ was statistically significantly higher (Mann-Whitney test) than that observed in control samples (taken before exposure). Significant statistical differences were observed considering both the parameters scored (percent of damage DNA in the Comet tail, and tail moment of the Comets).

Another statistical analysis ( $\chi^{2}$ or chi-square test) has been carried out considering the five classes of DNA damage reported by Anderson et al. [17]. Table 6 and figure 4 show the percentages of cells for both control mice and exposed mice, belonging to the various classes of damage (absent, low, medium, high and total).

Data obtained from the experiments in both the Ciampino and Vetralla cellars show that perinatal exposure to radon emissions induces a significant increase in micronuclei frequencies (ME/1,000E) both in newborn mice and in mice exposed during intrauterine phase.

Some differences in the two experiments should be noted: in Ciampino, the exposure was almost totally neonatal (from birth until 18 days after) compared with the exposure in Vetralla which was mainly intrauterine (about 19 days).

Despite these differences both experiments gave the same result; in mice from Ciampino, a ME frequency increase was observed with a radon exposure lower $\left(260 \mathrm{kBq} \mathrm{h} / \mathrm{m}^{3}\right)$ than that recorded in the Vetralla experiment $\left(1,090 \mathrm{kBq} \mathrm{h} / \mathrm{m}^{3}\right)$. 
Table 5 Damage as assessed by the Comet assay. $N=$ number of mice; $n . a .=$ not available; significance respect to control: $\mathbf{a}=\boldsymbol{P}<\boldsymbol{0 . 0 5}$.

\begin{tabular}{lllll}
\hline & $\mathrm{N}$ & Number of cells & DNA damage (\%) & Tail moment \\
\hline Control (before exposure) & 3 & 324 & $9.98 \pm 2.82$ & $6.40 \pm 3.24$ \\
Exposure 200 $\left[\mathrm{kBq} \mathrm{h} / \mathrm{m}^{3}\right]$ & 5 & 523 & $9.36 \pm 3.32$ & $8.98 \pm 4.99$ \\
Exposure $1,160\left[\mathrm{kBq} \mathrm{h} / \mathrm{m}^{3}\right]$ & 8 & 852 & $16.29 \pm 4.89^{\mathrm{a}}$ & $21 \pm 13.86^{\mathrm{a}}$ \\
\hline
\end{tabular}

Table 6 Percentages of cells with DNA damage absent, low, medium, high, and total; significance respect to control: $c$ $=P<0.001$.

\begin{tabular}{llll}
\hline$\%$ DNA damage & \% cells in Controls & $\begin{array}{l}\text { \% cells for Exp. 200 } \mathrm{kBq} \\
\mathrm{h} / \mathrm{m}^{3}\end{array}$ & $\begin{array}{l}\text { \% cells for Exp. 1,160 kBq } \\
\mathrm{h} / \mathrm{m}^{3}\end{array}$ \\
\hline No damage $(<5 \%)$ & 32.1 & 34.04 & 28.64 \\
Low damage $(5 \div 20 \%)$ & 54.32 & 56.98 & 33.57 \\
Medium damage $(20 \div 40 \%)$ & 12.96 & 8.79 & $30.87^{\mathrm{c}}$ \\
High damage $(40 \div 95 \%)$ & 0.62 & 0.19 & $6.92^{\mathrm{c}}$ \\
Total damage $(>95 \%)$ & 0 & 0 & 0 \\
\hline
\end{tabular}

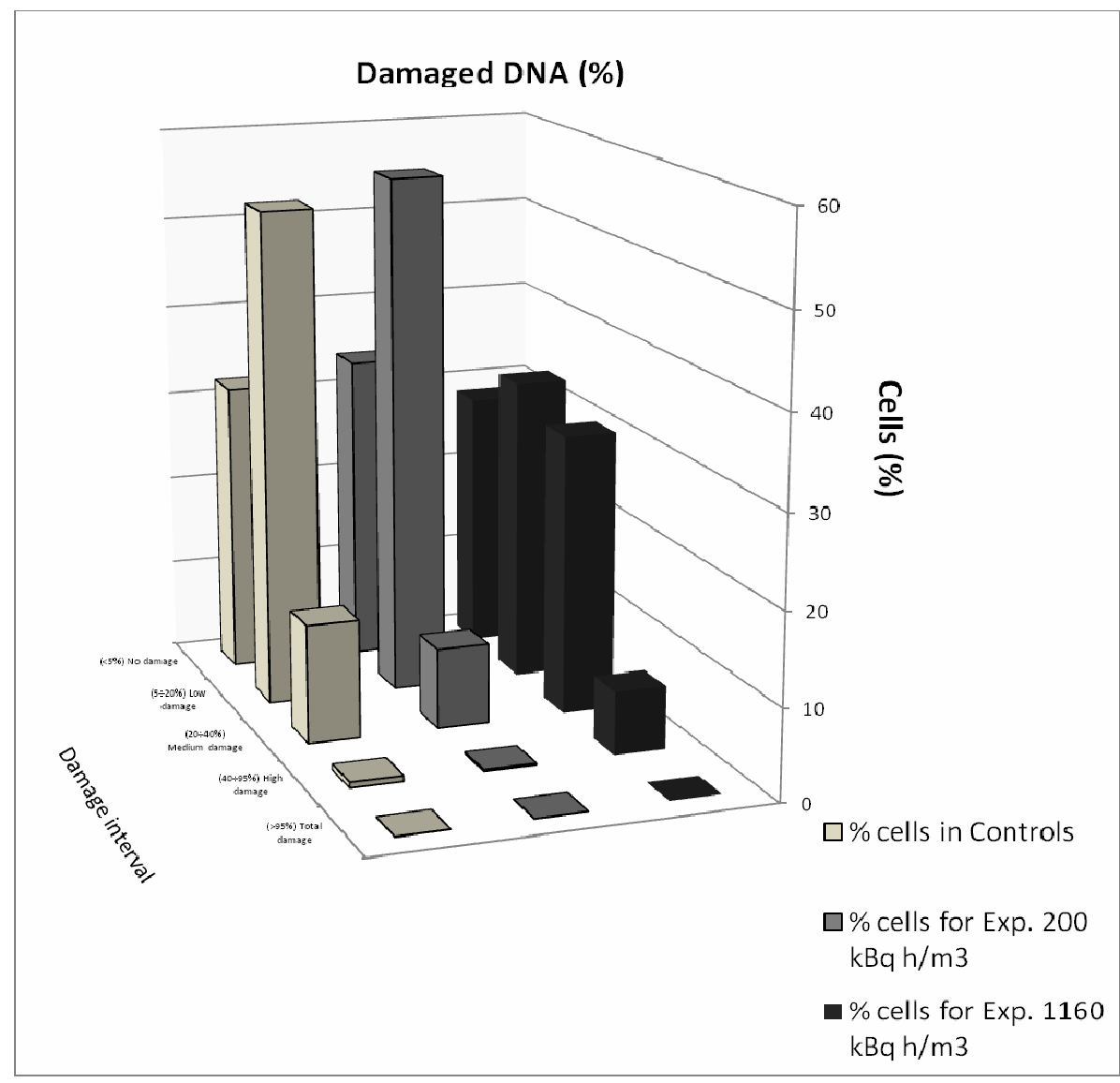

Fig. 4 Histogram of percentages of cells with DNA damage absent, low, medium, high, and total.

The difference observed between the two groups in the tests could be due to the differing period of exposure to radon and its decay products, indicating a higher degree of susceptibility during the postnatal period.
These results confirm that concentrations of radon decay products, such as bismuth and polonium (the main radioactive isotopes emitting alpha particles) are significantly lower in foetal tissues than in mothers $[18,19]$. Similarly, Kendall [20] has also shown that 
concentrations of radionuclides in embryonic tissues are almost systematically lower than the concentrations found in the tissues of the mother, and that the first part of a newborn's life (breastfeeding) is a period in which the absorbed dose is higher.

The same results were observed in the experiments performed with adult mice in the Vetralla cellar. Exposure to radon emissions induces a significant increase in micronuclei frequencies in peripheral blood erythrocytes (ME/1,000E). Final exposure, after more than thirty days (1st experiment: $1,700 \mathrm{kBq} \mathrm{h} / \mathrm{m}^{3}$; 2nd experiment: 1,160 $\mathrm{kBq} \quad \mathrm{h} / \mathrm{m}^{3}$ ) caused a statistically significantly higher frequency of ME than that observed in the control samples (taken before exposure).

The results highlighted by the Micronucleus test were confirmed in the second experiment carried out on adults, through the application of the Comet assay. This test, has, in fact underlined a statistically significant increase in DNA damage after exposure to radon than the damage detected in the control samples (taken before the exposure).

\section{Conclusions}

In conclusion, the work presented here confirms, on the basis of experimental evidence conducted on mice whose the biological model is perfectly comparable to the human species as already observed in previous studies [21-25], the effects caused by prolonged exposure to radon gas emissions.

In particular, the present study aims to highlight that workers in certain subterranean environments (bank vaults, catacombs, etc.), individuals living in homes constructed of tufaceous material and those who have settled in volcanic areas are all subject to potential genetic risks.

This study has shown a particular sensitiveness to radon and its decay products that is not as strong in murine embryos, protected by the placental tissues but appears in newborn mice, which already display genetic damage from exposure levels $\left(260 \mathrm{kbq} / \mathrm{m}^{3}\right)$ lower than those that cause genetic damage in adults and embryos (about $1,000 \mathrm{kbq} / \mathrm{m}^{3}$ ). It would therefore be appropriate to carry out further studies on this issue, in order to propose the most suitable prevention strategies in terms of social-health.

Indoor radon levels are affected by the soil composition under and around the buildings, and by the easiness with which radon enters the houses. Homes that are very close to each other can have different indoor radon levels. In addition, precipitation, barometric pressure, climate change parameters, hydrogeological phenomena and other factors can cause radon levels to vary from month to month or day to day, which is why both short- and long- term tests are available. The graphics showing the measurements of radon concentration registered in the cellars can be a good illustration of the varying of the radon levels in a confined environment. However, exposure obtained in the two experiments, can be used to say that the area of Vetralla could due to higher concentrations. Of course it depends by the soil composition of the area.

\section{Conflict of Interests}

The authors declare no conflict of interests regarding the publication of this paper.

\section{Acknowledgments}

We would like to thank: Prof. Fabrizio Aumento (Tuscia University, Viterbo), Doctor Massimo Esposito ("U-Series", Bologna) for their technical help and giving access to their facilities and instruments; D'Ambrosi, Marcuz and Megna families for use of the Ciampino cellars and Di Carlo and Gomeno families for the use of the Vetralla cellar; the Research Group composed by Prof. Felipe Cortés, Santiago Mateos, Nuria Pastor and Paula Daza at the Department of Cell Biology, Faculty of Biology, University of Seville (Spain) for their technical help, their warm welcome and access to their facilities too. Thanks also to: Prof. Caterina Tanzarella and Dr.ssa 

between in utero and Neonatal Exposures

Luisa Anna Ieradi for kind suggestions and helpful instruction; Doctorate School of Industrial and Environmental Hygiene directed by Prof. I. Figà-Talamanca; PRIN 2012 project "Effetti dei cambiamenti climatici sulle microteriocenosi terrestri" (Effects of climate change on terrestrial microtheriocoenoses); Prof. P. Brandmayr. Thanks to Zach Butcher for the careful proof reading.

\section{References}

[1] UNSCEAR (United Nations Scientific Committee on the Effects of the Atomic Radiation), "Sources and Effects of Ionizing Radiation," United Nations, New York, 2000.

[2] Ruano-Ravina, A., Ruosteenoja, E., Schaffrath, R. A., Tirmarche, M., Tomáek, L., Whitley, E., Wichmann, H. E., and Doll, R. 2005. "Radon in Homes and Risk of Lung Cancer: Collaborative Analysis of Individual Data from 13 European Case-control Studies." British Medical Journal 330 (7485): 223.

[3] Schuttmann, W. 1993. "Schneeberg Lung Disease and Uranium Mining in the Saxon Ore Mountains (Erzg ebirge)." American Journal of Industrial Medicine 23 (2): 355-68.

[4] Greenberg, M., and Selikoff, I. J. 1993. "Lung Cancer in the Schneeberg Mines: a Reappraisal of the Data Report." The Annals of Occupational Hygiene 37 (1): 5-14.

[5] IARC - International Agency for Research on Cancer, "Man-made Mineral Fibres and Radon. IARC Monographs on the Evaluation of Carcinogenic Risks to Humans 43." IARC, Lyon, 1998.

[6] Darby, S. C., Whitely, E., Howe, G. R., Hutchings, S. J., Kusiak, R. A., Lubin, J. H., Morrison, H. I., Tirmarche, M., Tomásek, L., Radford, E. P., Roscoe, R. J., Samet, M. J., and Yao, S. X. 1995. "Radon and Cancers Other Than Lung Cancer in Underground Miners: a Collaborative Analysis of 11 Studies." Journal of the National Cancer Institute 87 (5): 378-84.

[7] Nelson, S. L., and Grosovsky, A. J. 1995. "Evidence for a Gene Distal to HPRT which Restricts the Recovery of Large Deletions." Environmental Molecular Mutagenesis 25: 39-43.

[8] Schlegel, R., and Mac Gregor, J. T. 1982. "The Persistence of Micronuclei in Peripheral Blood Erythrocytes: Detection of Chronic Chromosome Breakage in Mice." Mutation Research 104: 367-9.

[9] Rommens, C. C., Ringeard, C., and Hubert, P. 2001.
"Exposure of Red Bone Marrow to Ionising Radiation from Natural and Medical Sources in France." Journal Radiological Protection 21: 209-19.

[10] Hellmann, B., Friis, L., Vaghef, H., and Edling, C. 1999. "Alkaline Single Cell Gel Electrophoresis and Human Biomonitoring for Genotoxicity: a Study on Subjects with Residential Exposure to Radon." Mutation Research 442: 121-32.

[11] Fukutsu, K., Ya mada, Y., Zhuo, W., and Koizumi, A. 2005. "Induction of Micronuclei in Rat Tracheal Epithelial Cells Following Radon Exposure at Air-liquid Interface Culture." International Congress Series 1276: 251-3.

[12] Udroiu, I., Cristaldi, M., Ieradi, L. A., Bedini, A., Giuliani, L., and Tanzarella, C. 2006. "Clastogenicity and Aneuploidy in Newborn and Adult Mice Exposed to $50 \mathrm{~Hz}$ Magnetic Fields." International Journal of Radiation Biology 82 (8): 561-7.

[13] Ieradi, L. A., Cristaldi, M., Ermenegildi, A., La Barbera, L., Radicchi, L., Renzopaoli, F., Esposito, M., and Lombardi, S. 2008. "Mutagenic Effects in Mice Exposed to Radon-222 Emissions in Latium Region (Italy)." Fresenius Environmental Bulletin 17 (9b): 1420-5.

[14] Daza, P., Torreblanca, J., and Moreno, F. J. 2004. "The Comet Assay Differentiates Efficiently and Rapidly between Genotoxins and Cytotoxins in Quiescent Cells." Cell Biology International 28: 497-502.

[15] Singh, N. P., Mc Coy, M. T., Tice, R, R., and Schneider, E. L. 1988. "A Simple Technique for Quantitation of Low Levels of DNA Damage in Individual Cells." Experimental Cell Research 175: 184-91.

[16] Fairbairn, D. W., Olive, P. L., and O'Neill, K. L. 1995. "The Comet Assay: a Comprehensive Review." Mutation Research 339: 37-59.

[17] Anderson, D., Yu, T. W., Phillips, B. J., and Schmezer, P. 1994. "The Effect of Various Antioxidants and Other Modifying Agents on Oxygen-radical-generated DNA Damage in Human Lymphocytes in the COMET Assay." Mutation Research 307: 261-71.

[18] ICRP, "Doses to the Embryos and Fetus from Intakes of Radionuclides by the Mother. ICRP Publicationn 88." Annals of the ICRP 31 (1-3) (Oxford Elsevier Science), 2001.

[19] Stather, J. W. 2003. "Dose Coefficients for the Embryo and Foetus following Intakes of Radionuclides by the Mother." Journal of Radiological Protection 22: 7-24.

[20] Kendall, G. M., Fell, T. P., and Harrison, J. D. 2009. "Dose to Red Bone Marrow of Infants, Children and Adults from Radiation of Natural Origin." Journal of Radiological Protection 29: 123-38. 

between in utero and Neonatal Exposures

[21] Little, C. C. 1937. "US Science Wars against an Unknown Enemy: Cancer." Life 2: 11-7.

[22] MacKey, B. E., and Mac Gregor, J. T. 1979. "The Micronucleus Test: Statistical Design and Analysis." Mutation Research 64 (3): 195-204.

[23] Waterston, R. H., et al. 2002. "Initial Sequencing and Comparative Analysis of the Mouse Genome." Nature
420: 520-62.

[24] Paigen, K. 2003. "One Hundred Years of Mouse Genetics: an Intellectual History. I. The Classical Period (1902-1980)." Genetics 163: 1-7.

[25] Paigen, K. 2003. "One Hundred Years of Mouse Genetics: an Intellectual History. II. The Molecular Revolution (1981-2002).” Genetics 163: 1227-35. 